\title{
Uncivil Society: How democracy is being undermined from within
}

Edition 1, 2020

Professor Vedi Hadiz

DOI: 10.37839/MAR2652-550X1.4

When I was a young democracy activist in Indonesia, my colleagues and I wanted to strengthen civil society against President Soeharto's authoritarian state. It hardly occurred to us that there might be groups, such as those based on identity politics, which may seek to marginalise various minorities and that they could arise from our precious civil society.

But this is exactly what a newer generation of democracy advocates now confront: the reality that they not only face hindrances from the state but also from civil society groupings. Some of these operate in the name of religion while others thrive on hyper-nationalism, including the paramilitary wings of diverse associations, prone to using violence and coercion. This is happening in a country lauded as the new model of democracy in Southeast Asia and the third largest democracy in the world.

Before Indonesia, Thailand was touted as Southeast Asia's model democracy. Yet, there too, educated members of the urban middle class, who are usually assumed to group together for democratic purposes, have instead helped to reinstall militarydominated authoritarianism. In India, civil society organisations linked to Narendra Modi's ruling Bharatiya Janata Party have helped to drive policies that show how democracy can be - paradoxically - used for repressive purposes. Hence, the nearly one century old Rashtriya Swayamsevak Sangh (RSS) has been at the forefront of violent actions against India's large Muslim minority as well as secular groupings. Their activities have given rise to apprehension that India is being reconceived as a Hindu nation. 
Lest these developments be thought a malady of newer, non-Western democracies, in the USA civil society groups such as the Tea Party have contributed for many years to the erosion of democratic values. Their presence ultimately paved the way for the presidency of Donald Trump and practices that are now wreaking havoc on American democracy. The rise of Trump is associated with the resurgence of populism globally, including in European democracies, where highly illiberal if not overtly anti-democratic political parties have recently made gains.

So perhaps it is high time to re-evaluate more seriously many commonly held rosy assumptions about the relationship between civil society and democracy. We should be paying more attention to the rise of civil society groups around the world, which will increasingly pose a challenge to democracy as we know it. These can range from exclusivist ethnic or religious organisations or gun-toting militias all the way to xenophobic groupings now all too easily found in rich, modern societies.

What is clear is that the liberal triumphalism greeting the end of the Cold War seems out of place now. Such triumphalism had led the World Bank to argue that a vibrant civil society was necessary for economic success, assuming that it would be politically and economically liberal. At the same time, political scientists had become immersed in 'transitology', with its singular interest in democratic 'transitions' and 'consolidations'. Civil society would play a big role in envisaged successful democratisations.

But how do we address democratic retreat even where democracy has been longentrenched?

A considerable change in mindset would be required. This entails dismissing the notion that there is some sort of automatic relationship between a 'strong' civil society and democratisation. It is a difficult task because civil society's long association with democracy goes back at least to the classic work of Alexis de Tocqueville, 'Democracy in America', written in the 19th century. More recently, Robert Putnam's influential work suggested that 'social capital' glued civil society 
together as the basis for modern democratic life.

It has since become easy to overlook that civil society may be dominated by antidemocratic interests simply because they win out in concrete political struggles. Most infamously, the Nazis did so in the 20th century.

Today, much of the discussion about the 'crisis of democracy' has focussed on populisms around the world. At the most basic level, populism involves a conception of politics in which the 'good masses' confront 'bad elites,' including those who may have taken control of intermediary institutions like parties and parliaments.

Yet American right-wing populism has been partly funded by the billionaire Koch brothers. In Australia, the mining magnate Clive Palmer poured $\$ 90$ million on the last election, pushing for policies that have helped shift the country's political centre to the right. In Indonesia too, there were links between the still wealthy family of the New Order-era dictator, Soeharto, and groups espousing populist versions of Islamic politics. These had supported the Prabowo candidacy in the 2019 presidential election.

So, the reality is that assorted elites have climbed onto the populist bandwagon, exploiting whatever long-simmering frustrations there are with the economy or with political institutions in different countries. Their self-interested actions have helped to shape the evolution of civil society.

Thus, rather than being fuelled by liberal pluralist values, some civil society organisations grow because of the insecurities of significant portions of the population - in a world where precarity and internal inequalities are developing at a startling rate. Contra the followers of Tocqueville or Putnam, they peddle identity politics or tough law and order agendas or flourish on insularity and xenophobia. While the Hong Kong protests tempt us to think of civil society mounting a final stand against democratic regression, in fact in many locations around the globe civil society groups are enthusiastically pulling democracy down. 
Main image: April 13, 2019. An Indonesian paramilitary group in Jakarta. (Photo by GOH CHAI HIN/AFP via Getty Images) 